\title{
SWOT Analysis in Determining the Management Strategy of Rendani River Catchment Area in Manokwari District
}

\author{
Bernadetta M.G. Sadsoeitoeboen ${ }^{1,3, *}$ Marlon Ivanhoe Aipassa ${ }^{2}$ \\ Muhammad Sumaryono ${ }^{2}$ Yohanes Budi Sulistioadi ${ }^{2}$
}

\author{
${ }^{1}$ Student of the Doctoral Program at Faculty of Forestry, Mulawarman University, Campus of Gunung Kelua, Jl. \\ Penajam, Samarinda \\ ${ }^{2}$ Faculty of Forestry, Mulawarman University, Campus of Gunung Kelua, Jl. Penajam, Samarinda \\ ${ }^{3}$ Faculty of Forestry, Papua University, Jl. Gunung Salju Manokwari \\ *Corresponding author. Email: $\underline{\text { b.sadsoeitoeboen@unipa.ac.id }}$
}

\begin{abstract}
The establishment of a new status for the Wosi Rendani forest area, which was previously a protected forest, has become an area for other uses, causing the area to become more open, as evidenced by changes in the land cover and the land use. On the one hand, the Rendani River is a source of clean water for Manokwari city. This underlies the need to conduct a study on the internal and external factors in the Rendani River catchment to develop strategies and steps for managing the area. Area management strategies to maintain hydrological functions obtained by using a SWOT analysis are: through the conservation of the Rendani River Catchment Area (DTA) and water resources management in collaboration with communal rights owners, other communities, universities, community organizations, and the private sector, where local governments continue to carry out coordination and supervision functions.
\end{abstract}

Keywords: SWOT, Internal Factors, External Factors

\section{INTRODUCTION}

Land use and land cover are essentially different even though they both describe the earth's surface's physical condition. Land use as related to human activities on a plot of land [1]. In contrast, land cover is more of a physical manifestation of objects covering land without questioning human activities on these objects. The rapid development of infrastructure, on the one hand, can open up the accessibility of the community. Still, on the other hand, there are consequences of an increase in life necessities, which have further implications for the environment. Changing forest zones' status to non-forest zones has increased forest clearing and other uses of forest land. The change in the status of the protected forest zone of Wosi Rendani to a zone for other uses has disrupted the hydrological protection function. On the other hand, the Rendani River is one of the suppliers of community water needs.
The water need is the amount/volume of water needed by the community to support all activities, including clean domestic water for household and nondomestic needs for industrial activities, tourism, places of worship, social areas, public places, and other commercial places. The need for water, especially for domestic activities, is mostly determined by the population and the amount of consumption per capita. The minimum requirement for each person for clean water per day, according to the Minister of Public Works Regulation Number 14/PRT/M/2010 concerning Minimum Service Standards for Public Works and Spatial Planning, is 60 liters. Population growth and land-use changes also determine non-domestic water needs for social, industrial and institutional activities. This estimated need can reach $20 \%$ to $25 \%$ of total water production [2].

Furthermore, the quantity of clean water supply increases from year to year. However, it is not sufficient 
to supply the needs of all residents, especially in big cities. The problem of meeting water needs for the community lies in water resources availability and how to manage these water resources.

According to the Presidential Decree No.7 of 2004 concerning Water Resources, water resources management is an effort to plan, implement, monitor, and evaluate the implementation of water resources conservation, utilization of water resources, and control of the destructive force of water. The management is carried out based on sustainability, balance, public benefit, integration and harmony, justice, independence, transparency, and accountability. It is also managed in a comprehensive, integrated, and environmentally friendly manner to realize the sustainable use of water resources for the people's greatest welfare. Integrated water resources management requires coordination of water, land, and related resources to optimize the resultant economy and social welfare properly without disturbing the stability of essential ecosystems [3].

Integrated management is intended so that management can be carried out from upstream to downstream. Political/administrative boundaries often limit watershed management activities, so ecosystem boundaries cannot be utilized [4]. The purpose of watershed management is to maximize socio-economic benefits from all land use activities in the watershed. It is adjusted to the watershed characteristics (physical, biological, social, economic, and cultural) to be managed. There are three general targets to be achieved in watershed management: rehabilitation of abandoned land/land that is still productive but cultivated in a manner that does not respect the principles of soil and water conservation, protection of lands that are generally sensitive to erosion or landslides or lands that are thought to require rehabilitation measures in the future, and increase or development of water resources that can be achieved by regulating one or more components of the watershed ecosystem which are expected to influence hydrological processes.

The water potential (total discharge) of four springs in the Wosi Rendani zone is $7011 . \mathrm{sec}^{-1}$, where the water potential is still not fully utilized [5]. On the other hand, the very rapid regional openness due to changes in the zone's function causes the possibility of disruption of the hydrological system, which results in a drastic reduction in water potential. By taking advantage of this zone's strengths and opportunities and minimizing the existing weaknesses and threats, it is hoped that this study will find out what strategies and management steps can be taken in the watershed so that the function of the zone can be sustained systems [3].

\section{METHODS}

This research uses in-depth interviews and SWOT analysis to develop strategies and steps for managing the Rendani River catchment. Supporting data is data on biophysical conditions, which is the initial study data in the same location which is part of this study.

\subsection{In-depth Interview Methods}

The in-depth interview method was carried out without a structured interview guide, directly through face-to-face between the interviewer and the interviewee. There was a relatively long social interaction [6]. Interview data collected from the respondents was about the Rendani River catchment's current condition and the level of urgency for its management in the future. All respondents are representative of the population (representing local communities, traditional leaders/customary rights owners, and technical agencies). Respondents are all parties who have direct contact with the use and management of the Rendani River catchment.

\subsection{SWOT Analysis}

SWOT analysis is carried out on two aspects, namely internal factors consisting of strengths and weaknesses and external factors consisting of opportunities and threats. The formulation of the strategy is obtained from a combination of each internal factor and external factor.

1) SO (strengths and opportunities) strategy that takes advantage of all strengths to make the most of the opportunities

2) ST (Strength and Threat) strategy that uses strength to overcome threats

3) WO strategies (Weaknesses and Opportunities) that take advantage of existing opportunities to minimize current weaknesses.

4) WT strategy (Weaknesses and Threats) which seeks to minimize weaknesses and avoid threats

Step Analysis with the SWOT Matrix is carried out as follows:

1) Create a matrix of internal factor evaluation and evaluation of external factors to obtain internal and external factors.

2) Determine each factor's weight based on the level of importance on a scale of 1 to 5 . Scale 5 (very important); 4 (important); 3 (moderate); 2 (not important), 1 (very insignificant).

3) Give a rating of each factor on a scale of 1 to 4 . The higher the value (close to or equal to 4), the more urgent the element will be. 


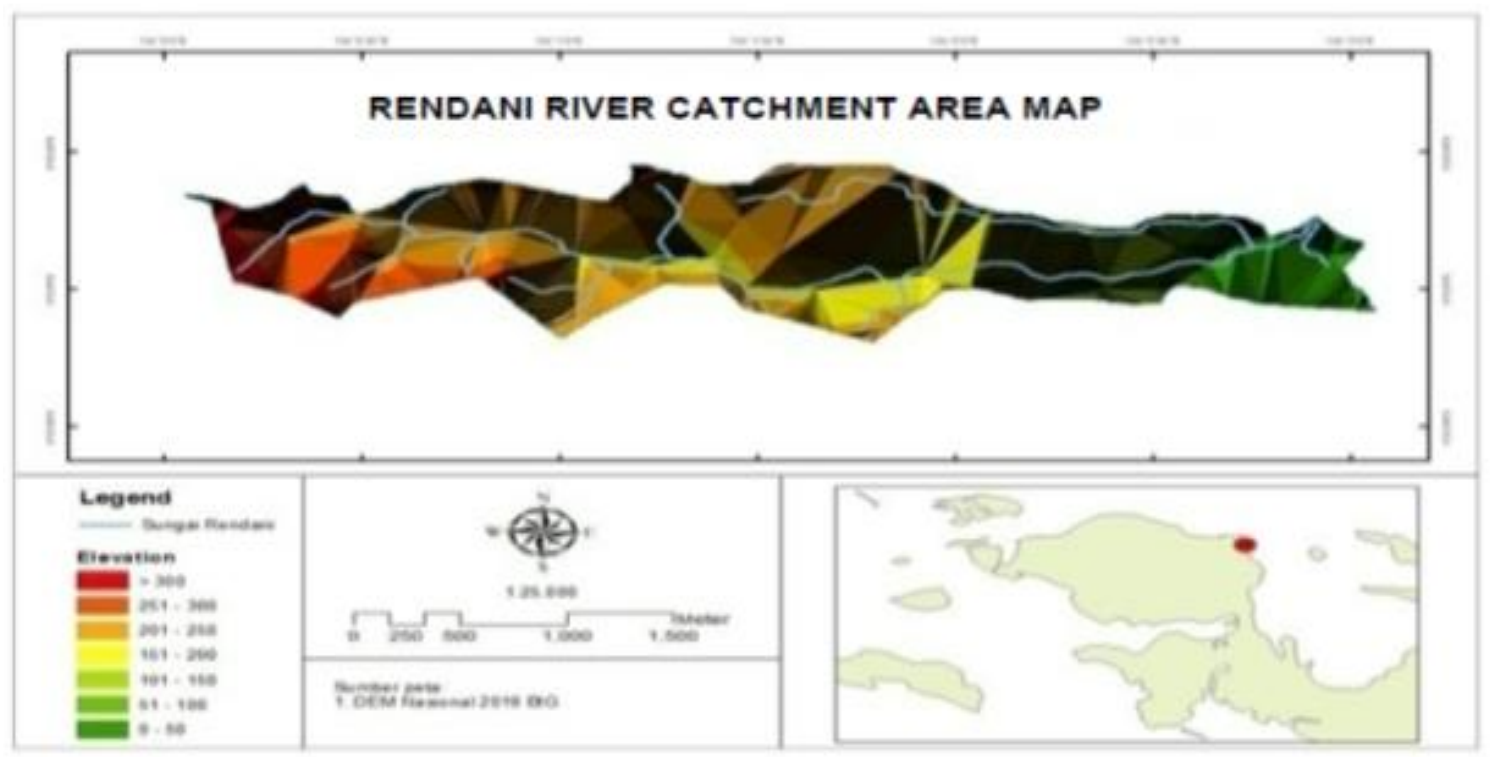

Figure 1 Map of the Rendani Manokwari River Catchment Area

4) Determine the quadrant for determining the choice of strategy based on the coordinates of the two points.

5) Determine the management steps in the chosen strategy.

\section{RESULTS AND DISCUSSION}

Part of the Rendani River Catchment Zone (DTA) is included in the Wosi Rendani forest zone, originally a protected zone in the Manokwari Regency zone. The enactment of the Wosi Rendani forest zone as a protected zone for the province of West Papua based on the Decree of the Governor of West Irian Province No.18 / GIB / 1969 aims to maintain the function of the land and regulate water management (hydrology). The Rendani River catchment is included in the Wosi River Basin. It is in the Wosi Rendani Forest zone located administratively in Wosi sub-district, West Manokwari District, Manokwari Regency at coordinates $134^{\circ} 0 ' 8.2$ "- 134 ${ }^{\circ} 47^{\prime}$ 'LS and 052'26.9"- $0^{\circ} 53^{\prime} 14.2^{\prime \prime}$ East Longitude with an area of 383.31 hectares. Located at an altitude ranging from 10 to 320 meters above sea level ( $\mathrm{m}$ asl). Rendani River has seven tributaries, and the length of the main river is $6,263 \mathrm{~m}[5,7]$

Map of the designation of forest and water areas for Irian Jaya Province (according to the Minister of Forestry Decree No. 891/KPTS-II/1999 concerning the designation of forest areas in the provincial area of the Irian Jaya region covering an area of 42,224,800 hectares, strengthened with a Map of Conservation Forest Areas and Waters for the Province West Papua (Annex to Decree of the Minister of Forestry Number 710 of 2014) and Regional Regulation of West Papua Province Number 04 of 2013 concerning the Spatial Plan for West Papua Province which states that this area is an area for other uses (APL).

\subsection{Biophysical Conditions of the Rendani River}

The Rendani River catchment consists of one large river and seven tributaries. The Rendani River is one of the four rivers that are the source of water used by the Manokwari Regional Drinking Water Company (PDAM) to meet the people's clean water needs. The current water discharge used for PDAM is only $101 . \mathrm{sec}^{-}$ ${ }^{1}$ from the available water discharge, reaching $4481 . \mathrm{sec}^{-}$ 1 [5].

The land cover area obtained from the land cover map of the Ministry of Environment and Forestry of the Republic of Indonesia from 2009 to 2017 and DEM 2018 shows that there are five types of land cover/land use in the Rendani River catchment area. The total area of 383.31 ha consisting of primary dryland forest (HLKP), secondary dryland forest (HLKS), settlement (PEM), mixed dryland agriculture (PLKC), and open land (airport).

Climate data which was obtained from the Geophysical Meteorology and Climatology Agency of Rendani Manokwari Station for the last 20 years (19982017) show that the climate in the Manokwari region and its surroundings is type A (very wet) with an average monthly rainfall of $209.83 \mathrm{~mm}$ [8]. The mean infiltration rate on all covers ranged from 0.020 to $2.342 \mathrm{~mm} . \mathrm{sec}^{-1}$ with a minimum rate of $0.022 \mathrm{~mm} . \mathrm{sec}^{-1}$ occurs at PEM closure, while a maximum rate of 3.195 mm. $\sec ^{-1}$ occurs at HLKS.

Soil types in the Rendani River catchment area are red and yellow podsolic soil types. Soil texture is a physical property that reflects the size of soil particles. Soil structure reflects the composition of primary soil particles (sand, dust, and clay) and of secondary particles or a combination of primary particles that form 
larger aggregates [9]. The research area's land is classified as a dusty clay texture class with generally lumpy angular structures. The sand fraction percentage ranges from 12.02 to $45.05 \%$, the dust fraction ranges from 54.67 to $70.92 \%$, and the clay fraction ranges from 0.27 up to $17.06 \%$. The groundwater content for each land cover is relatively the same, ranging from 21.61 to $33.94 \%$. The land portion in all land cover in the Rendani River catchment is at 58.77 to $78 \%$. Soil Mass Density ranged from 0.901 to $1.146 \mathrm{gr} . . \mathrm{cm}^{-3}$. The percentage of $\mathrm{C}$-organic in the soil in the land cover ranges from $1.02 \%$ to $1.35 \%$. Permeability in each land cover type ranges from 0.11 to $5.49 \mathrm{~cm}_{\text {.hour }}{ }^{-1}$ (class medium).

\subsection{Determination of Management Strategy}

The management strategy of the Rendani River catchment area is determined by the SWOT (Strength, Weakness, Opportunity, Threat) analysis method to identify various factors systematically to formulate a strategy for companies, contemplate strategies and manage strategies that are based on the interaction between internal factors, namely strength, and opportunities, with external factors, namely weaknesses and threats. The analysis was carried out through the following stages: (1) identification of internal and external factors (IFI and IFE matrices), (2) create a SWOT matrix to evaluate internal and external factors, (3) compile and determine alternative management strategies [10-17]. It can be seen in Table 1 and Table 2.

\subsection{Evaluation and Determination of Strategy Options}

The weighting is based on each factor's urgency level on a scale of 1 (very insignificant) to 5 (very important). The rating scale ranges from 1 (decreasing) to 4 (getting better). The strength of each factor (internal and external) can be seen from the sum of the scores [13]. If the value is close to 1 , then there are more weaknesses than strengths (internal factors) or more threats than opportunities (external factors). If the score is close to 4, then there are more strengths than weaknesses (internal factors) or more opportunities than threats (external factors). The calculation in Table 3 shows the sum of the internal factor scores of 3.0 (getting closer to the 4.0 value). This indicates that there are more internal strengths than internal weaknesses. Likewise, the sum of the scores on external factors was 2.79 (closer to 4.0), meaning more external opportunity factors than threat factors. It can be seen in Table 3 .
Table 1. IFE and IFI Matrices

\begin{tabular}{|c|c|}
\hline Internal Factors & External Factors \\
\hline $\begin{array}{l}\text { Strength } \\
\text { 1. The rainfall factor } \\
\text { supports the ongoing } \\
\text { hydrological cycle. } \\
\text { 2. Soil physical } \\
\text { properties support soil } \\
\text { infiltration. River } \\
\text { characteristics (flat) so } \\
\text { that the flow is weak } \\
\text { 3. Secondary forest } \\
\text { cover still exists }\end{array}$ & $\begin{array}{l}\text { Opportunity } \\
\text { 1. The existence of a } \\
\text { national river border } \\
\text { protection regulation } \\
\text { 2. Commitment of } \\
\text { customary rights } \\
\text { owners to protect the } \\
\text { area around the } \\
\text { spring. } \\
\text { 3. Utilization of water by } \\
\text { BUMD, private sector, } \\
\text { and individuals } \\
\text { 4. The existence of a } \\
\text { forest and land } \\
\text { rehabilitation program } \\
\text { from the local } \\
\text { government }\end{array}$ \\
\hline $\begin{array}{l}\text { Weakness: } \\
\text { 1. Taking forest } \\
\text { products by the } \\
\text { community } \\
\text { 2. Activities to open } \\
\text { garden land }\end{array}$ & $\begin{array}{l}\text { Threats: } \\
\text { 1. The selling value of } \\
\text { the land increases } \\
\text { 2. The absence of } \\
\text { regional regulations } \\
\text { toregulate customary } \\
\text { rights. } \\
\text { 3. The absence of } \\
\text { regional regulations to } \\
\text { regulate residential } \\
\text { areas } \\
\text { 4. The population in DTA } \\
\text { increases }\end{array}$ \\
\hline
\end{tabular}


Table 2. SWOT Matrices

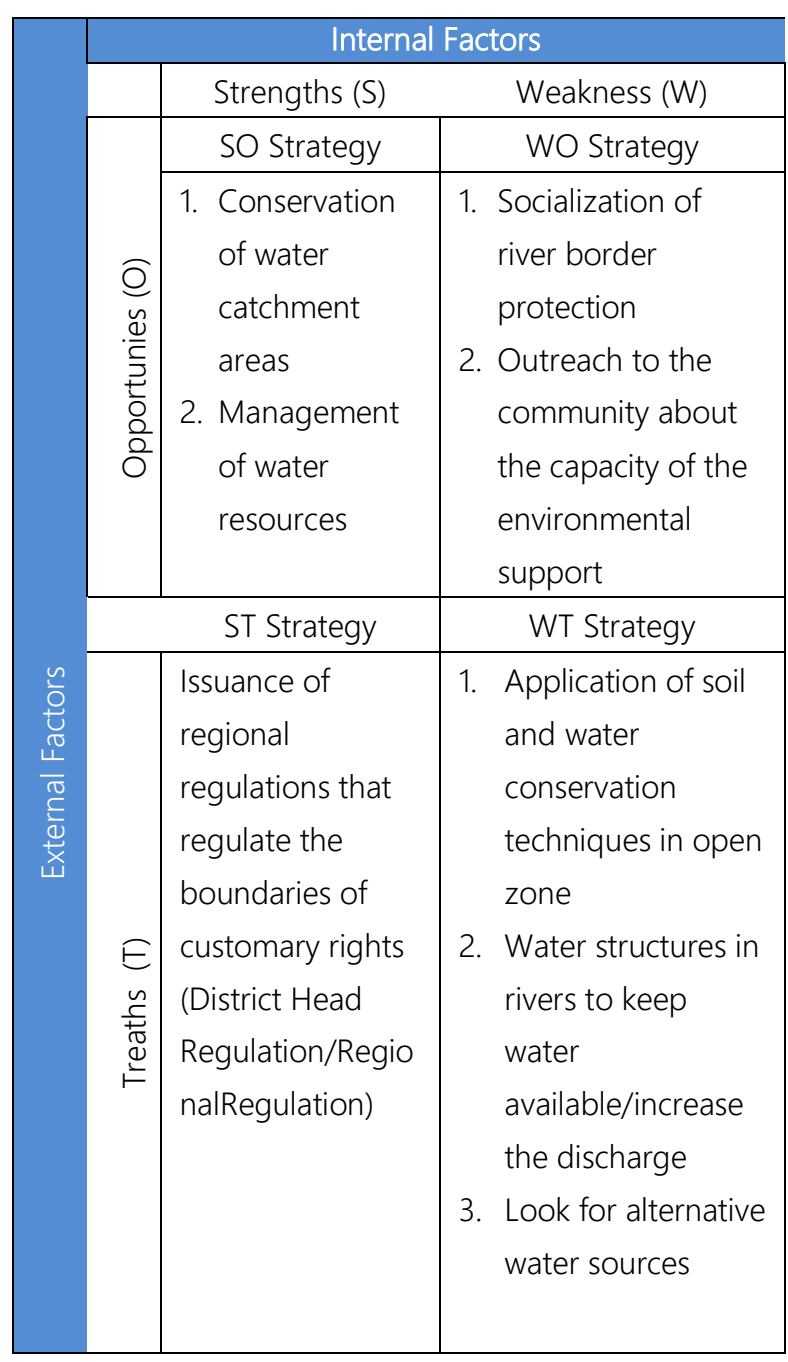

A choice of alternative management strategy of the Rendani River catchment will be based on identifying internal and external matrices. The choice of strategy for catchment management is known through the quadrant's selection due to the projection of the value of the difference between internal factors and the difference between external factors on quadrant I, namely SO Strategy (Figure 2) [18]. In carrying out the management strategy, we must use all the strengths that have to take advantage of the opportunities that exist, namely conducting conservation of the Rendani River catchment area and managing existing water resources using internal strength.

The Rendani River catchment area management can achieve the expected goals in carrying out conservation and management if there is integrated coordination between technical agencies, the community, and the private sector. The participation and responsibility of all parties involved are expected in this management. The local government's role is needed to manage an object that is important for the wider community's welfare. It is necessary to have rules that bind all parties in planning the regional layout to make it easier to implement conservation programs $[19,20]$. It is required to formulate regional policies to regulate the management system, including handling community involvement. The government's role can be done by making provincial regulations and implementing programs with the community that support these conservation efforts [21]. There is a need for a common perception in managing, in addition to a comprehensive, integrated, and non-overlapping policy [22]. Management should not only be administrative, but it can be operated either independently by the government or by other parties [23]. Collaborative management is needed in managing an area to prevent negative perceptions from the surrounding community [24]. Furthermore, there is a need for the socialization of regulations to foster a common understanding and a sense of concern to play a role in river management [25].

There is a need for an integrated, solid, comprehensive, and holistic approach in water resources management. Being aware of water management's complexity, the 2nd World Water Forum in The Hague in March 2000 revealed that one of the causes of the water crisis is the poor management of water resources. Likewise, the World Summit on Sustainable Development (WSSD), held in Johannesburg, South Africa, in early September 2002, raised water as a priority program in sustainable development. Management of water resources requires efforts to empower water resources for various interests, such as domestic, agricultural, industrial, urban, residential, plantation, and other interests in a sustainable manner [26]. 
Field observations indicate that there has been no effort to protect water sources from upstream to downstream of the Rendani River. In the upstream area, it is seen that the extraction of timber forest products is seen. In the middle, it is dominated by land clearing for new residential settlements and community farms. In contrast, it is dominated by land clearing for settlement, business places, and infrastructure development in the downstream area. Management can also be done using the existing blocks by involving the community in maintaining forest areas [27]. The part of the Rendani River where water is mostly used is in the middle. This is because the middle part of the river is still accessible, and it has more water discharge (due to the confluence of several tributaries). In addition, the riverbanks are still covered with vegetation, and they are not directly located in residential areas (not yet polluted with garbage).

Table 3. Value of Weight, Rating and Score of Internal and External Factors

\begin{tabular}{|c|c|c|c|c|c|}
\hline \multirow{2}{*}{ No } & \multirow{2}{*}{ Internal/External Factors } & \multicolumn{2}{|c|}{ Weightage } & \multirow{2}{*}{ Rating } & \multirow{2}{*}{ Score } \\
\hline & & Value & Value & & \\
\hline & \multicolumn{5}{|l|}{ Strength } \\
\hline 1 & The rainfall factor supports the ongoing hydrological cycle & 4.00 & 0.17 & 3.00 & 0.50 \\
\hline 2 & Physical properties of soil support soil infiltration & 2.00 & 0.08 & 3.00 & 0.25 \\
\hline 3 & River characteristics is flat so that the flow is weak & 2.00 & 0.08 & 3.00 & 0.25 \\
\hline \multirow[t]{3}{*}{4} & Secondary forest cover still exists & 4.00 & 0.17 & 4.00 & 0.67 \\
\hline & Total (Strength) & 12.00 & 0.50 & & 1.67 \\
\hline & \multicolumn{5}{|l|}{ Weakness } \\
\hline 1 & Forest products area taken by the community & 3.00 & 0.13 & 3.00 & 0.38 \\
\hline 2 & Deforestation for farming & 3.00 & 0.13 & 3.00 & 0.38 \\
\hline 3 & Settlement development increased & 4.00 & 0.17 & 2.00 & 0.33 \\
\hline \multirow[t]{4}{*}{4} & Topography / slope of land & 2.00 & 0.08 & 3.00 & 0.25 \\
\hline & Total (Weakness) & 12.00 & 0.50 & & 1.33 \\
\hline & \multicolumn{4}{|c|}{ Difference of Total Internal Factors } & 0.34 \\
\hline & \multicolumn{4}{|l|}{ Opportunity } & \\
\hline 1 & There is a national river border protection regulation & 4.00 & 0.17 & 4.00 & 0.67 \\
\hline 2 & $\begin{array}{l}\text { Commitment of customary rights owners to protect the } \\
\text { area around the spring }\end{array}$ & 3.00 & 0.13 & 2.00 & 0.25 \\
\hline 3 & $\begin{array}{l}\text { Utilization of water by BUMD, private sector and } \\
\text { individuals }\end{array}$ & 4.00 & 0.17 & 3.00 & 0.50 \\
\hline \multirow[t]{3}{*}{4} & $\begin{array}{l}\text { The existence of a forest and land rehabilitation program } \\
\qquad(\mathrm{RHL}) \text { by the local government }\end{array}$ & 3.00 & 0.13 & 3.00 & 0.38 \\
\hline & Total (Opportunity) & 14.0 & 0.58 & & 1.79 \\
\hline & \multicolumn{4}{|l|}{ Threat } & \\
\hline 1 & The increasing selling value of land & 3.00 & 0.13 & 2.00 & 0.25 \\
\hline 2 & $\begin{array}{l}\text { The absence of regional regulations to regulate customary } \\
\text { rights (ulayat rights) }\end{array}$ & 2.00 & 0.08 & 3.00 & 0.25 \\
\hline 3 & $\begin{array}{l}\text { The absence of regional regulations to regulate residential } \\
\text { areas }\end{array}$ & 2.00 & 0.08 & 3.00 & 0.25 \\
\hline \multirow[t]{3}{*}{4} & $\begin{array}{l}\text { The increasing number of population in DTA (adat land } \\
\text { zone) }\end{array}$ & 3.00 & 0.13 & 2.00 & 0.25 \\
\hline & Total (Threat) & 10.0 & 0.42 & & 1.00 \\
\hline & \multicolumn{4}{|c|}{ Difference of Total External Factors } & 0.79 \\
\hline
\end{tabular}


PDAM, the private sector, and individuals carry out the use of river water. PDAM uses an underground water container to collect water and then channelled it using a pipe to the reservoir. Individual users also use the piping system. The river's location (source of water) is lower than the settlement (more than $50 \mathrm{~m}$ ), so a pump machine is needed to draw water. There are drinking (bottled) water companies that also collect water but through a PDAM reservoir. However, the water was just being organized and channelled, and there was no visible and special treatment of water, such as filtering at water sources,

The steps for managing the Rendani River catchment that can be carried out following the choice of strategy are a collaboration with universities, community, and private organizations to carry out comprehensive conservation in the Rendani River catchment from upstream to downstream. One of the most effortless to do is by planting along the banks of the Rendani River. To prevent landslides, it can be done through appropriate conservation techniques. Making terraces can be done to protect the soil from being damaged due to erosion [28]. It is also necessary to intensively reforest and regreen the land to reduce the danger of erosion. The water resource management can be carried out through coordination with regional drinking water managers, individual and group users. There must be the supervision of the extraction and distribution of water from the Rendani river source [29]. There are seven principles in water resources management: sustainability, the principle of balance, public benefit, integrity, justice, independence, and transparency [30]. To ensure that water resources management can be carried out and provide services for the community's interests, there is a need for a standard procedure of control based on the principle of balance between conservation and water resource utilization [31].

\section{CONCLUSION}

The strategy for managing the Rendani River catchment that can be implemented is a combination of strengths as internal factors and utilizing existing opportunities as external factors, namely carrying out conservation and management of water resources in the Rendani River catchment through multi-stakeholder coordination, including government agencies, the private sector, and the community, ulayat owners and other communities.

\section{ACKNOWLEDGMENTS}

This paper was written as part of dissertation research. Thanks to the promoters for their guidance. All parties who helped until this paper can be published.

\section{REFERENCES}

[1] T.M. Lillesand, R.W Kiefer, J.W. Chipman, Remote Sensing and Image Interpretation, Fifth Edition, John Wiley \& Son, US, 2003.

[2] R.J. Kodoatie, R. Sjarief, Pengelolaan Sumberdaya Air Terpadu, Penerbit Andi, Yogyakarta, 2005.

[3] R.J. Kodoatie, R. Sjarief, Tata Ruang Air, Penerbit Andi, Yogyakarta, 2010.

[4] C. Asdak, Hidrologi dan Pengelolaan Daerah Aliran Sungai, Gadjah Mada University Press, 2004.

[5] A.S. Sinery, Mahmud, Fungsi Kawasan dan Strategi Pengelolaan Hutan Lindung Wosi Rendani Kabupaten Manokwari, XIII (2), 2014, 131140. https://media.neliti.com/media/publications/30108

[6] P.S. Rahmat, Penelitian Kualitatif, Equilibrium, 5(9), 2009, pp. 1-8.

[7] Dinas Kehutanan dan Perkebunan Kabupaten Manokwari, Laporan Hasil Identifikasi Hutan Lindung Wosi Rendani Kabupaten Manokwari Provinsi Papua Barat, 2008. DOI:https://doi.org/10.14710/mkts.v13i3.3927

[8] Badan Meteorologi Klimatologi dan Geofisika (BMKG) Stasiun Manokwari, Data Curah Hujan Kabupaten Manokwari, 2018.

[9] K.A. Hanafiah, Dasar-Dasar Ilmu Tanah, Divisi Buku Perguruan Tinggi, PT Raja Grafindo Persada, Jakarta, 2005. http://ejournal.fordamof.org/ejournal-litbang

[10] D. Amanah, SWOT Analysis of The Wildlife Park of Medan, Indonesia Info Teknis International Journal of Economic, Commerce and Management, 3(10), 2015, pp. 500-509. https://www.researchgate.net/publication/3142992 $\underline{57}$

[11] M. Ardiansyah, Analisa Peningkatan Kinerja Sistem Irigasi Kalibawang Kabupaten Kulon Progo Daerah Istimewa Yogyakarta, Prosiding Seminar Nasional Aplikasi Teknologi Wilayah, 2010. https://atpw.wordpress.com

[12] E. Gurel, SWOT Analysis; A Theoretical Review, The Journal of International Social Research, 10(151), 2017, pp. 994-1006. DOI:http://dx.doi.org/10.17719/jisr.2017.1832

[13] F. Rangkuti, Analisis SWOT: Teknik Membedah Kasus Bisnis, Gramedia Pustaka Utama, 2006.

[14] Rujehan, Model Pemanfaatan dan Strategi Manajemen Hutan Lindung: Studi Pengelolaan 
Hutan Lindung Sungai Wain di Kalimantan Timur, Mulawarman University Press, 2017.

[15] R. Sinulingga, M.Baiquni, S. Purnama, Pengelolaan Sumberdaya Air untuk Pengembangan Pariwisata di Pulau Pari Kepulauan Seribu DKI Jakarta, Majalah Geografi Indonesia, 29(2), 2015, pp. 177-186. https://sinta.ristekbrin.go.id/authors/detail

[16] E. Susan, A.J. Jackson, L.E. Niclas, Recent Research on Team and Organizational Diversity: SWOT Analysis and Implications, Journal of Management., 29(6), 2015, pp. 801-83. DOI: https://doi.org/10.1016/S0149-2063(03)00080-1

[17] H. Weihrich, The SWOT Matrix: A Tool for Situational Analysis, Long Range Planning, 15(2), 1982, pp. 54-66. DOI: doi:10.1016/00246301(82)90120-0

[18] N. Estika, Suprihatin, M. Yani, Analisis dan Formulasi Strategi Ketersediaan Air Bersih di Lokasi Transmigrasi (Studi Kasus: Kecamatan Lasalimu Selatan Kabupaten Buton), Jurnal Pengelolaan Sumberdaya Alam dan Lingkungan, 7(2), 20017, pp. 114-121. DOI: https://doi.org/10.29244/jps1.7.2.114-121

[19] S. Akhmaddian, Pengaruh Kebijakan Pemerintah Daerah dalam Konservasi Sumber Daya Air Terhadap Kesadaran Lingkungan Masyarakat Kabupaten Kuningan, Jurnal Unifikasi, 4(1), 2017, pp. 1-13. DOI: https://doi.org/10.25134/unifikasi.v4i1.477

[20] Sutedjo. Keterpaduan kebijakan lingkungan dan tataruang, Jurnal Yustisia, 72, 2007, pp. 15-26. http://garuda.ristekbrin.go.id/documents/detail/148 $\underline{561}$

[21] S. Akhmaddhian, Dinamika Peran Pemerintah Daerah dalam Mewujudkan Hutan Konservasi berdasarkan Undang-undang Nomor 41 Tahun 1999 tentang Kehutanan (Studi di Kabupaten Kuningan), Jurnal Hukum, 13(3), 2013, pp. 446456.

DOI: http://dx.doi.org/10.20884/1.jdh.2013.13.3.250

[22] K. Ginoga, M. Lugina, D. Djaenudin, Kajian Kebijakan Pengelolaan Hutan Lindung (Policy Analysis of Protection Forest Management), Jurnal Penelitian Sosial \& Ekonomi, 2(2), 2005, pp. 203232

file://C:/Users/DELL/AppData/Local/Temp/ginog a2.pdf

[23] Arnita, Pengelolaan Hutan dalam Rangka Otonomi Daerah oleh Pemerintah Aceh Utara, Kanun Jurnal
Ilmu Hukum, 59, 2013, pp. 81-97. http://jurnal.unsyiah.ac.id/kanun

[24] M.I. Aipassa, S. Karno, Upaya Perbaikan Fungsi Hidrologis pada Sub DAS Batu Besaung Guna Mengantisipasi Banjir di Kota Samarinda, Jurnal Kehutanan Tropika Humida, 5(1), 2012, pp. 25-37.

[25] M.I. Aipassa, Sutedjo, A.S. Sinery, Ibrahim, Potensi dan Rencana Pengelolaan Hutan Kota Sangatta, Deepublish, Yogyakarta, 2015.

[26] Sangkawati, J. Hadihardaja, Pemberdayaan Sumberdaya Air untuk Berbagai Kepentingan Secara Berkelanjutan, Media Komunikasi Teknik Sipil, 13(3), 2005, pp. 117-127.

[27] Sumaryono, A. Rusdi, H.F.Z. Peday, Y.R. Yohanes, Potensi dan Pengembangan Hutan Lindung Ayamaru, Penerbit Deepublish.

[28] Sarlina, M.I. Aipassa, Kajian Rehabilitasi Hutan dan Lahan pada Sub DAS Ranjuri di Kecamatan Marawola Barat Kabupaten Sigi Provinsi Sulawesi Tengah, Jurnal Kehutanan Tropika Humida, 4(2), 2011, pp. 136- $149 . \quad \mathrm{http}: / /$ jurnalkehutanantropikahumida.zohosites.com

[29] K. Sitepu, Beberapa Alternatif Mendukung Konservasi Hutan dan Air serta Kelangsungan Hidup, Jurnal Ilmiah Abdi Ilmu, 1(1), 2008, pp. 26 33.

[30] A. Sarminingsih, Kajian Upaya Konservasi Sumberdaya Air dalam Peningkatan Kesadaran Masyarakat, Jurnal Presipitasi, 5(2), 2008, pp. 4248. DOI: https://doi.org/10.14710

[31] Sallata, Konservasi dan Pengelolaan Sumberdaya Air Berdasarkan Keberadaannya Sebagai Sumberdaya Alam, Info Teknis EBONI, 12(1), 2015, pp. 75-86. 